\title{
Mengukur Implementasi Distribusi Barang Berdasarkan Kerangka Islam di Bidang Peternakan dan Konfeksi Pakaian Muslim Kota Tasikmalaya - Jawa Barat
}

\author{
Asep Yusup Hanapia, Fatimah Zahra Nasution, \\ Ade Komaludin, lis Surgawati \\ Universitas Siliwangi \\ fatimahzahranasution@unsil.ac.id
}

\begin{abstract}
Abstrak
Islam memandang urgensi penerapan nilai-nilai halal tidak hanya pada aspek kebendaan, namun sampai pada aspek pelaksanaan way of life (muamalah). Dalam perekonomian, kegiatan distribusi menjadi salah satu kegiatan penting selain konsumsi dan produksi. Bisnis berbasis Islam tidak akan sempurna tanpa kegiatan distribusi yang sesuai dengan prinsip-prinsip Islami. Nilai ketaubidan (oneness), rasa syukur (gratefulness), keadilan (justice) dan kebebasan (freedom) menjadi dimensi dalam pengukuran variabel distribusi Islami yang dianalisis dalam penelitian ini. Penelitian ini bertujuan untuk mengetabui bagaimana implementasi prinsip-prinsip Islam dalam kegiatan distribusi yang dilakukan oleb produsen makanan dan bukan makanan di Kota Tasikmalaya, Jawa Barat. Data dikumpulkan dengan menggunakan instrumen penelitian berupa kuesioner yang dibagik.an kepada 51 orang responden yang terdiri dari pengusaba di bidang peternakan mewakili produsen makanan, sedangkan dari 88 orang responden yang terdiri dari pengusaha konfeksi pakaian muslim mewakili produsen bukan makanan. Hasil penelitian menunjukkan bahwa pemahaman pengusaha ternak dan konfeksi pakaian muslim terhadap prinsip distribusi Islami masing-masing sebesar 99,22\% dan 98,11\%. Dimensi yang paling dominan diterapkan dari prinsip distribusi Islam, baik oleh pengusaha ternak dan pengusaha konfeksi pakaian muslim adalah dimensi monoteisme (ketaubidan) dengan nilai rata-rata per item masing-masing 233,0 dan 416,56. Implikasi dari hasil penelitian ini mendorong pengusaha Muslim untuk menerapkan prinsip distribusi Islami dalam kegiatan bisnis mereka untuk mencapai kemashlahatan bagi masyarakat.
\end{abstract}

Kata Kunci: distribusi Islami, ketaubidan, kesyukuran, keadilan, kebebasan. 


\section{Dinar. Vol 7, No 1: Januari 2020. 46-61 \\ ISSN: 2460-9889 (Cetak) \\ ISSN: 2580-3565 (Online)}

https://journal.trunojoyo.ac.id/dinar/index

DOI: https://doi.org/10.21107/dinar

\section{Pendahuluan}

Perkembangan pemahaman dan ajaran ekonomi Islam saat ini menunjukkan efek yang nyata dalam kehidupan. Fenomena meningkatnya kesadaran masyarakat akan nilai-nilai religius khususnya bagi masyarakat muslim, menciptakan demand tersendiri terhadap barang dan jasa yang sesuai dengan syariat Islam (Ahmad, Rahman, \& Rahman, 2015). Seiring berjalannya waktu, konsep dan praktik ekonomi Islam tidak lagi hanya dipandang sebatas pada transaksi perbankan yang bebas dari sistem ribawi, namun telah sampai pada pelaksanaan kegiatan ekonomi yang esensi yakni kegiatan konsumsi, produksi dan distribusi (Aprianto, 2017).

Kepatuhan seorang muslim terhadap ajaran agamanya tentu diimplementasikan dalam kehidupan sehari-hari. Berbagai penelitian terkini membuktikan bahwa selain faktor harga, masyarakat muslim memiliki kecenderungan untuk memilih barang dan jasa yang sesuai dengan syariat Islam (Briliana \& Noviana, 2016; Nasution, Mandasari, \& Billah, 2018). Hal ini tentu didorong oleh peningkatan pengetahuan dan pemahaman masyarakat terhadap ajaran dan prinsip-prinsip syariah (Aisyah, 2016).

Peningkatan demand terhadap produk halal dari sisi konsumen tentu memberikan suntikan motivasi bagi produsen untuk menciptakan barang dan jasa yang halal pula. Dalam suatu produk, aspek halal, bersih, baik dan kriteria lainnya yang ditentukan dalam ajaran Islam merupakan pertimbangan penting bagi setiap muslim dalam memutuskan konsumsinya. Hal ini dikarenakan kualitas makanan, pakaian dan tempat tinggal menentukan nilai ibadah seorang muslim. Hadirnya berbagai produk baik makanan dan bukan makanan yang mengusung konsep islami telah jamak dijumpai di pasaran. Berbagai komunitas religius dan pengajian dikalangan masyarakat saat ini saling berlomba-lomba dalam mengkonsumsi produk-produk halal dan sesuai syariat Islam. Namun tak cukup sampai disini, secara komprehensif kesesuaian penerapan aspek syariat Islam haruslah mencakup seluruh aspek dalam kegiatan ekonomi termasuk proses distribusi.

Kegiatan distribusi merupakan penyaluran bagi hasil produksi, kekayaan, barang maupun jasa kepada masyarakat. Tujuan utama kegiatan distribusi adalah agar terjadi sirkulasi harta sehingga sumber daya yang ada dapat dinikmati oleh masyarakat dengan adil dan merata dan tidak hanya beredar diantara golongan tertentu saja. Hal ini sejalan dengan firman Allah dalam Alquran Surat Al-Hasyr ayat 7 sebagai berikut:

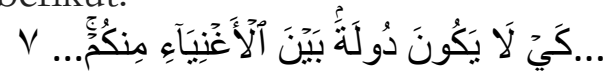

Artinya: ...supaya harta itu jangan beredar di antara orang-orang kaya saja di antara

kamu...

Kegiatan distribusi dalam Islam dapat berupa penyaluran barang, kesempatan, pendapatan dan harta dalam bentuk pembayaran upah, zakat, infaq, sedekah, wakaf, warisan, hibah, hadiah dan lain sebagainya (Ibrahim, 2015). Harta yang beredar dikalangan umat Islam diharapkan menjadi harta yang "bersih", dan membawa pengguna harta tersebut pada hal-hal yang bernilai ibadah kepada Allah Swt.(Lailatussufiani, Burhan, \& Multifiah, 2016). Selain memenuhi tuntunan ajaran agama, kegiatan distribusi juga mencakup aspek ekonomi, budaya, sosial (takaful) dan politik (Munthe, 2014). Kegiatan distribusi yang bebas nilai akan 
menyebabkan ketimpangan dan kesenjangan dalam berbagai aspek di masyarakat (Aprianto, 2018). Eksploitasi buruh, kemiskinan, penimbunan barang, ketimpangan ekonomi dan sosial merupakan fenomena yang terjadi akibat kegiatan distribusi yang bebas nilai.

Dalam Islam, kegiatan distribusi mencakup beberapa dimensi penting diantaranya nilai ketauhidan (oneness), kesyukuran (gratefulness), keadilan (justice) dan kebebasan (freedom). Nilai ketauhidan mengakui adanya keesaan Allah Swt. sebagai satu-satunya tuhan yang wajib disembah. Nilai kesyukuran merupakan rasa terima kasih yakni implementasi dari rasa cukup atas nikmat dan karunia yang telah diberikan Allah Swt., sehingga mendorong manusia untuk mau berbagi kepada sesamanya. Nilai keadilan bermakna penerapan sikap menempatkan sesuatu sesuai dengan ketentuannya, tunduk dan patuh serta menyesuaikan kehidupan dengan aturan syariat Islam merupakan implementasi dari nilai keadilan. Selain itu, keadilan dalam distribusi haruslah bersifat fleksibel dalam kerangka kebijakan yang fundamental guna memecahkan masalah ketidak-merataan dan ketidak-adilan dalam proses distribusi. Adapun nilai kebebasan bermakna adanya kebebasan individu bertindak atas harta dan kekayaan yang dimilikinya (Sari, 2014).

Penerapan optimal atas nilai-nilai islami dalam kegiatan distribusi ini diasumsikan akan ditemukan di wilayah yang memiliki penduduk beragama Islam. Kota Tasikmalaya dikenal dengan sebutan "kota santri" terletak di Kawasan Priangan Timur Provinsi Jawa Barat memiliki jumlah penduduk muslim sebesar 98,7 \% dari total populasinya (Jumlah Penduduk Menurut Kecamatan dan Agama yang Dianut di Kota Tasikmalaya, 2015, https://tasikmalayakota.bps.go.id). Dalam kawasan dengan kondisi masyarakat yang homogen beragama Islam, penerapan nilai-nilai syariat Islam tentu terlaksana dengan baik. Hal ini dikarenakan mayoritas masyarakat memiliki pemahaman religius yang sama.

Selain itu, Peraturan Daerah No. 12 Tahun 2009 tentang Pembangunan Tata Nilai Kehidupan Kemasyarakatan yang Berlandaskan pada Ajaran Agama Islam dan NormaNorma Sosial Masyarakat Kota Tasikmalaya juga mulai diterapkan dalam upaya menjunjung nilai kearifan lokal kota santri tersebut. Hal ini menjadi menarik untuk dikaji bahwa apakah keadaan demografis dan dukungan legal dari pemerintah daerah kota tersebut dapat membentuk pola kehidupan agamis di masyarakat termasuk dalam kegiatan distribusi.

\section{Metode Penelitian}

Penelitian ini dilakukan untuk mengukur penerapan prinsip syariat Islam dalam kegiatan distribusi yang dilakukan oleh produsen makanan dan bukan makanan di Kota Tasikmalaya Jawa Barat. Variabel yang diamati adalah variabel prinsip distribusi islami dengan beberapa dimensi yakni nilai ketauhidan (oneness), nilai kesyukuran (gratefulness), nilai keadilan (justice) dan nilai kebebasan (freedom). Metode penelitian yang digunakan adalah metode survei terhadap produsen makanan yang diwakili oleh pengusaha peternakan dan produsen bukan makanan yang diwakili oleh pengusaha konfeksi pakaian muslim.

Dalam hal menentukan ukuran sampel, penelitian ini menggunakan Teknik Proportionate Stratified Random Sampling dimana populasi mempunyai anggota/unsur yang tidak homogen dan berstrata secara proporsional. Data penelitian dikumpulkan melalui penyebaran kuesioner kepada 51 responden pengusaha di bidang peternakan dan 88 responden 
pengusaha di bidang konfeksi pakaian muslim. Kuesioner penelitian ini menggunakan skala Likert dimana responden memberikan konfirmasi jawaban atas pernyataan yang diberikan sesuai dengan skala ukur yang telah ditentukan yakni berbobot nilai 1 sampai 5 .

Tahapan analisis data dimulai dengan pengujian instrumen penelitian yang mencakup uji validitas dan uji reliabilitas untuk mengukur ketepatan dan keandalan kuesioner yang digunakan. Selanjutnya dilakukan analisis deskriptif terhadap instrumen penelitian. Analisis Nilai Jenjang Interval digunakan untuk mengukur klasifikasi penilaian dari setiap indikator dimensi yang diamati dan klasifikasi penilaian variabel prinsip distribusi islami. Uji beda dilakukan dengan menggunakan analisis Chi-Square untuk menganalisis ada tidaknya perbedaan tingkat penerapan dari dimensi distribusi islami yang diamati dalam penelitian ini serta dilanjutkan dengan menganalisis dimensi apa yang paling dominan diterapkan pada tiap-tiap sektor kajian yakni bidang peternakan dan konfeksi pakaian muslim.

\section{Hasil dan Pembahasan}

\section{Prinsip-Prinsip Syariah dalam Kegiatan Distribusi}

Sebagai agama yang membawa rahmat bagi sekalian alam, ajaran Islam telah mengatur seluruh aspek kehidupan manusia termasuk dalam bidang ekonomi. Sistem ekonomi Islam merupakan sistem ekonomi yang bersifat tauhid. Cerminan sifat tauhid atau ketuhanan dalam penerapan ekonomi Islam terdapat pada aspek aturan atau sistem yang harus dipedomani oleh para pelaku ekonomi (Rivai dan Buchari, 2009:2). Ekonomi Islam merupakan sebuah sistem ekonomi tersendiri. Sebagaimana ilmu ekonomi, kajian ekonomi Islam juga membahas tentang kegiatan inti ekonomi yaitu konsumsi produksi dan distribusi, dimana ketiganya saling berkaitan satu sama lain. Konsumsi merupakan faktor penting yang mendasari munculnya aktivitas produksi dan distribusi. Tanpa adanya kegiatan konsumsi pelaku ekonomi tidak akan terdorong untuk melakukan aktivitas produksi dan distribusi.

Dalam konteks pemasaran produk, istilah distribusi dimaknai sebagai aktivitas penyaluran barang maupun jasa dari produsen (penghasil) kepada konsumen (pengguna). Tanpa kegiatan distribusi, barang atau jasa tidak akan sampai dari produsen ke konsumen, sehingga kegiatan produksi dan konsumsi tidak lancar. Sebagai jembatan antara produsen dan konsumen, distribusi mempunyai peran signifikan dalam perputaran roda perekonomian masyarakat ataupun negara. Distribusi dalam perekonomian berarti penyaluran, pembagian sumber daya ekonomi kepada seluruh masyarakat dalam satu wilayah perekonomian tertentu untuk mencapai tujuan pemerataan dan keadilan.

Untuk mencapai kesejahteraan dan tujuan pemerataan tersebut, distribusi islami perlu diterapkan. Prinsip syariah dalam proses distribusi islami mencakup beberapa dimensi yakni nilai ketauhidan (oneness), kesyukuran (gratefulness), keadilan (justice) dan kebebasan (freedom) yang menjadi dimensi dalam pengukuran variabel prinsip distribusi islami yang dianalisis dalam penelitian ini.

\section{Nilai Ketauhidan (oneness)}

Berbicara konsep ketuhanan, Islam adalah satu-satunya agama yang menanamkan kepada penganutnya konsep ketuhanan yang bersifat taubidi. Praktik ekonomi Islam membawa kembali peran tuhan dalam kegiatan ekonomi dan kehidupan manusia. Artinya, 
dalam hal keyakinan (akidah) seorang muslim wajib meyakini bahwa Allah Maha Esa, Esa dalam Zat-Nya, Esa dalam sifat-Nya, dan Esa dalam perbuatan-Nya. Keyakinan atas keesaan Allah Swt. merupakan pondasi keimanan dan perkara yang mendasar dalam kehidupan seorang muslim. Dalam ajaran Islam, tauhid merupakan perintah yang utama dimana seluruh perintah Allah Swt. yang lainnya mengikuti perintah untuk bertauhid ini dan tidak akan bermanfaat kecuali dengan bertauhid terlebih dahulu (Turmudi, 2017). Di antara bukti yang menunjukkan bahwa tauhid merupakan perintah Allah Swt. yang terbesar terdapat dalam Alquran Surat An-Nisa ayat 36 sebagai berikut:

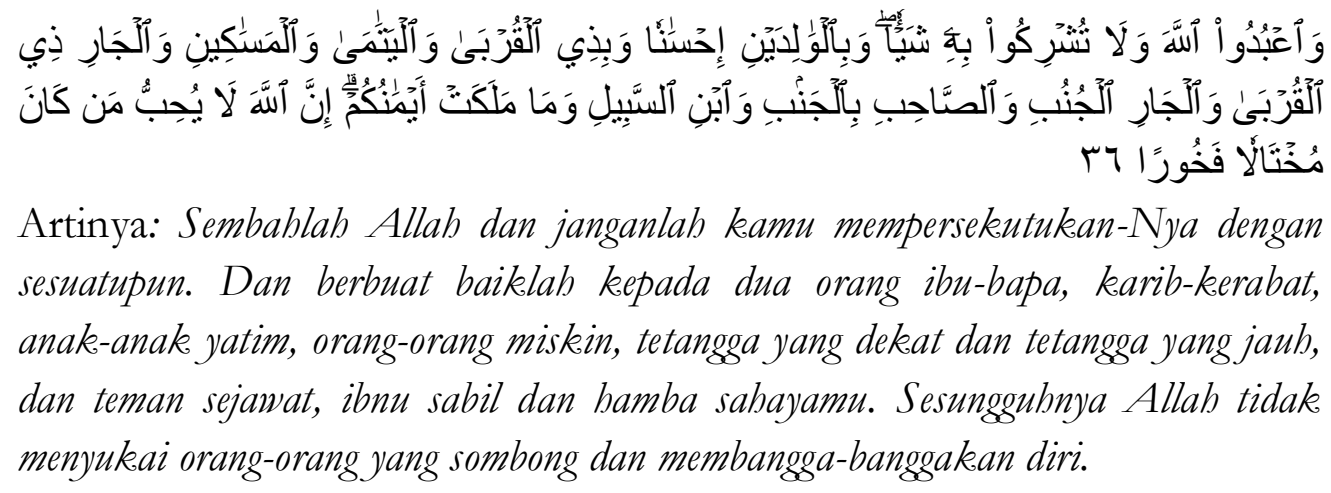

Implikasi dari nilai ketauhidan menuntun perilaku seorang muslim untuk melaksanakan kegiatan hidupnya sebagai perwujudan dari ibadah kepada Allah Swt. sebagaimana firman Allah Swt. dalam Alquran Surat Adz-Dzariyat ayat 56 sebagai berikut:

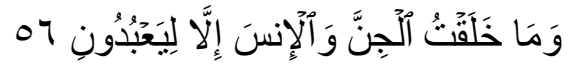

Artinya: Dan aku tidak menciptakan jin dan manusia melainkan supaya mereka mengabdi kepada-Ku.

Dalam ayat ini, Allah Swt. menjelaskan bahwa tujuan utama penciptaan makhluk adalah beribadah hanya kepada Allah Swt. saja. Oleh karena itu, tauhid adalah perintah yang terbesar dalam ajaran Islam, karena dengan melaksanakannya, seorang muslim dapat mewujudkan tujuan penciptaan dirinya.

\section{Nilai Kesyukuran (gratefulness)}

Rasa syukur mencerminkan rasa cukup dan tenang atas karunia dan pemberian Allah Swt. dalam kehidupan. Dalam perkara ibadah, seorang muslim diperintahkan untuk melihat dan mencontoh kepada orang yang lebih baik ibadahnya, namun dalam urusan harta, seorang muslim diperintahkan untuk melihat dan berempati terhadap orang yang lebih malang nasibnya. Dengan demikian rasa syukur akan memotivasi seorang muslim untuk meningkatkan ibadahnya dan menyalurkan harta kekayaannya, membagikan kebahagiaannya kepada sesama baik dari segi kuantitas maupun kualitasnya. Bersyukur merupakan perintah yang dijelaskan Allah Swt. dalam Alquran. Setelah Allah Swt. memberikan pertolongan, kemudahan dan kemampuan bagi manusia dalam mencari penghidupan selayaknyalah manusia bersyukur atas hal yang demikian dengan berempati kepada sesamanya. Hal inilah 
yang mendorong perilaku dalam distribusi islami sebagaimana perintah pada surat AlJatsiyyah ayat 12 sebagai berikut:

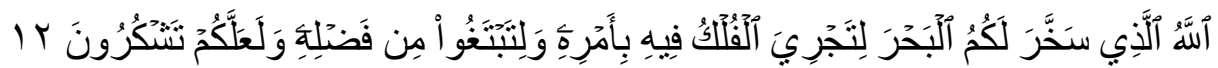
Artinya: Allah-lah yang menundukkan lautan untukmu supaya kapal-kapal dapat berlayar padanya dengan seizin-Nya dan supaya kamu dapat mencari karunia-Nya dan mudah-mudahan kamu bersyukur.

Islam menganjurkan agar umatnya mendistribusikan sebagian harta dan penghasilan mereka untuk membantu saudara-saudara mereka yang berkekurangan di bidang ekonomi. Sikap dermawan, ta'awun dan membagikan hartanya sesuai perintah Allah Swt. yang didorong oleh rasa syukur sebenarnya adalah kebutuhan asasi manusia karena dalam pelaksanaannya manusia yang memberi dan menerima akan merasakan ketenangan dan kebahagiaan yang tak ternilai (Rodin, 2016). Sebagaimana disebutkan dalam Alquran Surat Luqman ayat 12 sebagai berikut:

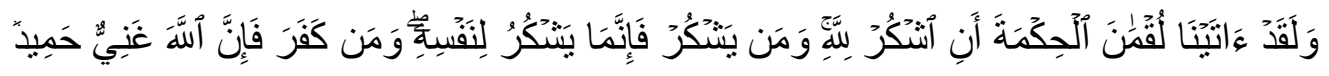

Artinya: Dan sesunggubnya telah Kami berikan bikmat kepada Luqman, yaitu:

"Bersyukurlah kepada Allah. Dan barangsiapa yang bersyukur (kepada Allah), maka sesunggubnya ia bersyukur untuk dirinya sendiri; dan barangsiapa yang tidak bersyukur, maka sesunggubnya Allah Maha Kaya lagi Maha Terpuji."

Sejalan dengan itu, dalam Alquran surat An-Naml ayat 40 Allah Swt. berfirman:

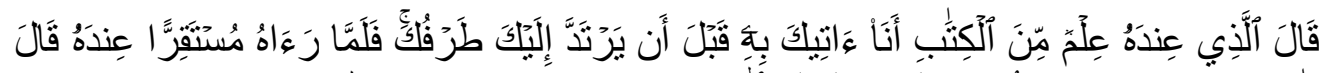

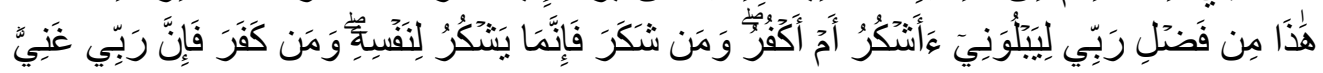

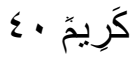

Artinya: Berkatalah seorang yang mempunyai ilmu dari Al Kitab: "Aku akan membawa singgasana itu kepadamu sebelum matamu berkedip". Maka tatkala Sulaiman melihat singgasana itu terletak di badapannya, iapun berkata: "Ini termasuk kurnia Tubanku untuk mencoba aku apakab aku bersyukur atau mengingkari (akan nikmat-Nya). Dan barangsiapa yang bersyukur maka sesunggubnya dia bersyukur untuk (kebaikan) dirinya sendiri dan barangsiapa yang ingkar, maka sesunggubnya Tubanku Maha Kaya lagi Maha Mulia."

\section{Nilai Keadilan (justice)}

Salah satu tujuan utama dalam sistem ekonomi Islam adalah mewujudkan keadilan dalam pendistribusian harta baik dalam kehidupan bermasyarakat maupun individu. Berbagai masalah dalam kehidupan ekonomi dan sosial di masyarakat dapat disebabkan oleh penyimpangan dalam pengalokasian dan pendistribusian sumber daya ekonomi. 
Penerapan distribusi berdasarkan prinsip-prinsip syariah bertujuan agar sirkulasi kekayaan meningkat dan menciptakan pembagian yang adil dan merata di antara berbagai komponen masyarakat, serta tidak memusatkan modal dan harta hanya pada sebagian kecil kelompok tertentu (Madnasir, 2011). Prinsip keadilan merupakan inti seluruh hukum yang mengatur kegiatan dalam ekonomi Islam. Keadilan bermakna menempatkan sesuatu sesuai pada tempat atau aturannya. Islam menghendaki keteraturan dan kesesuaian dan mengecam segala bentuk ketidakadilan, kebatilan dan kezaliman. Beberapa ayat Alquran menyatakan prinsip keadilan seperti dalam Alquran surat An-Nisa ayat 135.

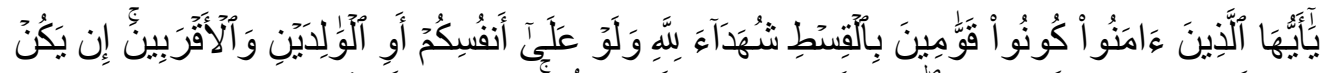

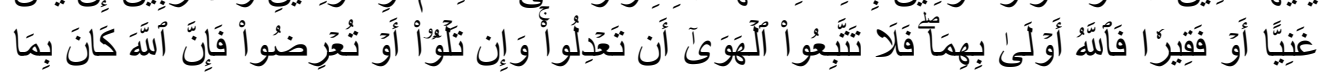

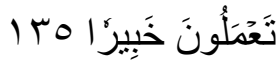

Artinya: Wahai orang-orang yang beriman, jadilah kamu orang yang benar-benar penegak keadilan, menjadi saksi karena Allah biarpun terhadap dirimu sendiri atau ibu bapa dan kaum kerabatmu. Jika ia kaya ataupun miskin, maka Allab lebih tabu kemaslabatannya. Maka janganlab kamu mengikuti hawa nafsu karena ingin menyimpang dari kebenaran. Dan jika kamu memutar balikekan (kata-kata) atau enggan menjadi saksi, maka sesunggubnya Allah adalah Maha Mengetahui segala apa yang kamu kerjakan.

Kemudian pada Surat An-Nisa ayat 29 sebagai berikut:

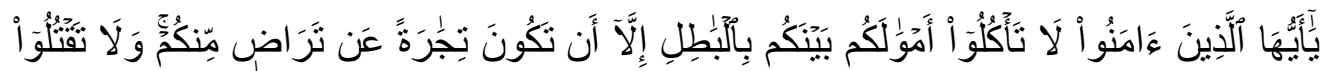

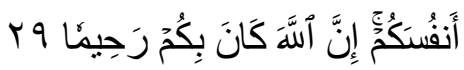

Artinya: Hai orang-orang yang beriman, janganlah kamu saling memakan harta sesamamu dengan jalan yang batil, kecuali dengan jalan perniagaan yang berlaku dengan suka sama-suka di antara kamu. Dan janganlah kamu membunub dirimu; sesunggubnya Allah adalah Maha Penyayang kepadamu.

Kemudian dalam Surat Al-Baqarah ayat 188 Allah Swt. berfirman sebagai berikut:

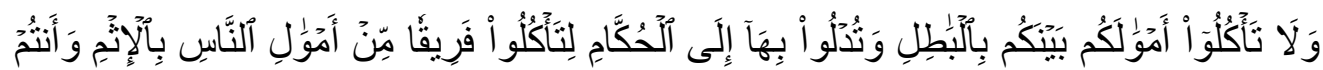

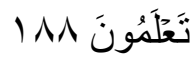

Artinya: "Dan janganlah sebahagian kamu memakan harta sebahagian yang lain di antara kamu dengan jalan yang bathil dan (janganlab) kamu membawa (urusan) barta itu kepada hakim, supaya kamu dapat memakan sebahagian daripada barta benda orang lain itu dengan (jalan berbuat) dosa, padahal kamu mengetahui."

\section{Nilai Kebebasan (freedom)}

Nilai kebebasan bermakna bahwa Islam menghormati kebebasan individu dan kelompok masyarakat dalam melakukan kegiatan ekonominya. Berdasarkan kerangka dan prinsip dasar muamalah dalam Islam, hukum kegiatan perdagangan dan bisnis adalah bebas 
(mubah) sampai ada larangan syar'i sebagai batasannya. Dengan kata lain, Islam memberikan kebebasan bagi umatnya dalam mengatur dan mengupayakan kehidupannya selama tidak melanggar syariat Islam seperti melakukan tindakan kezaliman baik terhadap diri sendiri maupun orang lain (Holis, 2016). Nilai kebebasan dalam Islam memberikan implikasi terhadap adanya pengakuan akan kepemilikan individu. Setiap hasil usaha seorang muslim dapat menjadi hak miliknya sehingga hal ini menjadi motivasi yang kuat bagi dirinya untuk melakukan aktivitas ekonomi. Ia akan berusaha sekuat tenaga untuk mencari kekayaan yang bebas digunakan dan disalurkan sesuai dengan kerangka Islam.

Kebebasan terkait distribusi berkenaan dengan kepemilikan atau kekayaan seseorang yang tidak dibatasi jumlahnya. Kebebasan disini adalah kebebasan dalam bertindak yang di bingkai oleh nilai-nilai agama dan keadilan. Secara alamiah, manusia memiliki sifat ingin memenuhi kebutuhan mereka sebaik mungkin. Dengan begitu, Islam memberikan kebebasan kepada manusia untuk memiliki kekayaan yang sebanyak-banyaknya. Namun demikian, disisi lain, Islam melarang umatnya berperilaku berlebih-lebihan dan bermewah-mewah. Oleh karenanya, kekayaan dan harta yang dikumpulkan, bukan digunakan untuk tujuan bermewahmewah, namun digunakan untuk pelaksanaan ibadah, termasuk penyaluran zakat, infak, sedekah, wakaf, waris, hadiah, hibah dan bentuk penyaluran harta yang dibenarkan dalam syariat Islam (Saparuddin, 2015).

\section{Profil Responden Penelitian}

Berdasarkan hasil pengumpulan data penelitian, karakteristik responden penelitian diklasifikasikan atas jenis kelamin, umur, status perkawinan dan tingkat pendidikan. Profil responden pada penelitian ini dirangkum dalam tabel 1 berikut:

\section{Tabel 1}

Profil Responden Pengusaha Peternakan dan Pengusaha Konfeksi Pakaian Muslim di Kota Tasikmalaya

\begin{tabular}{|c|c|c|c|c|c|}
\hline \multirow[b]{2}{*}{ Karakteristik } & \multirow[b]{2}{*}{ Kategori } & \multicolumn{2}{|c|}{ Pengusaha Peternakan } & \multicolumn{2}{|c|}{ Pengusaha Konfeksi } \\
\hline & & Frekuensi & Persentase & Frekuensi & Persentase \\
\hline \multirow[t]{3}{*}{ Jenis Kelamin } & Laki-laki & 50 & $98 \%$ & 73 & $83 \%$ \\
\hline & Perempuan & 1 & $2 \%$ & 15 & $17 \%$ \\
\hline & TOTAL & 51 & $100 \%$ & 88 & $100 \%$ \\
\hline \multirow[t]{6}{*}{ Umur } & $<25$ Tahun & 1 & $2 \%$ & 3 & $3 \%$ \\
\hline & $\begin{array}{l}26 \quad-35 \\
\text { Tahun }\end{array}$ & 5 & $9 \%$ & 11 & $13 \%$ \\
\hline & $\begin{array}{ll}36 \quad- & 45 \\
\text { Tahun } & \end{array}$ & 17 & $33 \%$ & 27 & $31 \%$ \\
\hline & $\begin{array}{l}46 \quad-55 \\
\text { Tahun }\end{array}$ & 14 & $28 \%$ & 24 & $27 \%$ \\
\hline & $>55$ Tahun & 14 & $28 \%$ & 23 & $26 \%$ \\
\hline & TOTAL & 51 & $100 \%$ & 88 & $100 \%$ \\
\hline Status & Belum kawin & 5 & $9 \%$ & 2 & $2 \%$ \\
\hline
\end{tabular}


Perkawinan

\section{Tingkat \\ Pendidikan}

$\begin{array}{ll}\text { Kawin } & 45 \\ \text { Duda } & 1 \\ \text { Janda } & 0 \\ \text { TOTAL } & \mathbf{5 1}\end{array}$

Tidak

Sekolah

Tidak Tamat

SD

Tamat SD 21

Tidak Tamat

SMP

Tamat SMP 6

Tidak Tamat

SMA

Tamat SMA 14

Tidak Tamat

Perguruan

0

Tinggi

Tamat

Perguruan 9

45

0

51

0

$2 \%$

$89 \%$

$0 \%$

$100 \%$

83

2

$95 \%$

1

88

$1 \%$

$0 \%$

0

$100 \%$

Tinggi

TOTAL

51

$0 \%$

0

$0 \%$

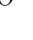

$41 \%$

21

$0 \%$

0

$0 \%$

1

$24 \%$

$12 \%$

20

$1 \%$

\section{$2 \%$}

0

$23 \%$

$28 \%$

31

$0 \%$

(4)

$0 \%$

1

$35 \%$

Dari beberapa karakteristik responden yang disurvei, mayoritas responden baik pengusaha peternakan maupun pengusaha konfeksi pakaian muslim berjenis kelamin lakilaki, dengan rentang umur 36-45 tahun. Jawaban terbanyak atas status perkawinan adalah kawin dengan rata-rata tingkat pendidikan terbanyak adalah tamat SD dan tamat SMA.

\section{Hasil Uji Validitas dan Reliabilitas Instrumen}

Pada responden pengusaha peternakan, uji instrumen dilakukan dengan uji validitas dan reliabilitas terhadap 134 pernyataan dalam kuesioner. Berdasarkan hasil pengujian validitas diketahui bahwa 25 item pernyataan atau sekitar 18,6\% item pernyataan tidak valid. Kemudian pada responden pengusaha konfeksi pakaian muslim, berdasarkan hasil pengujian validitas diketahui bahwa 31 dari 134 item pernyataan atau sekitar $23 \%$ item pernyataan tidak valid. Oleh karena itu, item-item tersebut tidak dimasukkan ke dalam tahapan pengolahan data selanjutnya.

Adapun hasil uji reliabilitas instrumen baik pada responden pengusaha peternakan dan pengusaha konfeksi pakaian muslim tergolong reliabel karena rhitung Cronbach's Alpha $0,750>r_{\text {tabel }} 0,233$ pada pengusaha peternakan dan $r_{\text {hitung }}$ Cronbach's Alpha 0,750 $>r_{\text {tabel }}$ 0,213 pada pengusaha konfeksi pakaian muslim. 
Dengan demikian, jawaban responden pengusaha peternakan selanjutnya dianalisis dari 109 pernyataan dan 103 pernyataan bagi pengusaha konfeksi pakaian muslim yang telah diuji validitas dan reliabilitasnya.

\section{Tingkat Pemahaman dan Nilai Jenjang Interval atas Penerapan Prinsip Distribusi Islami oleh Pengusaha Peternakan dan Konfeksi Pakaian Muslim di Kota Tasikmalaya}

Melalui penyebaran kuesioner yang berisi pernyataan-pernyataan dengan pilihan jawaban ya dan tidak, yang berkaitan dengan pemahaman responden atas prinsip distribusi islami, dapat dinyatakan bahwa pemahaman pengusaha ternak dan konfeksi pakaian muslim terhadap prinsip distribusi islami masing-masing sebesar 99,22 \% dan 98,11\%. Hal ini bermakna bahwa pelaku usaha yang diamati dalam penelitian ini memiliki tingkat pemahaman yang baik terhadap penerapan prinsip syariat Islam dalam kegiatan distribusi yang dilakukannya.

\section{Analisis Nilai Jenjang Interval Setiap Indikator dan Variabel Prinsip Distribusi Islami Pengusaha Peternakan}

Analisis selanjutnya adalah analisis Nilai Jenjang Interval (NJI) yang digunakan untuk mengukur klasifikasi penilaian dari variabel dan setiap indikator dimensi distribusi islami yang diamati terhadap 51 orang responden pengusaha peternakan. NJI dihitung dengan tahapan sebagai berikut:

Nilai tertinggi indikator penerapan prinsip distribusi islami pada

pengusaha peternakan: $51 \times 5=255$

Nilai terendah indikator penerapan prinsip distribusi islami pada

pengusaha peternakan: $51 \times 1=51$

Jumlah kriteria pernyataan sebanyak: 5

$$
\text { Maka NJI }=\frac{\text { Nilai Tertinggi }- \text { Nilai Terendah }}{\text { Jumlah Kriteria Pernyataan }}=\frac{255-51}{5}=40,8 \approx 41
$$

Dengan demikian, nilai 41 menjadi jarak interval dalam klasifikasi penilaian untuk setiap indikator penerapan prinsip distribusi islami oleh pengusaha peternakan dalam penelitian ini. Berikut ditampilkan dalam tabel 2:

\section{Tabel 2}

Klasifikasi Penilaian untuk Setiap Indikator Penerapan Prinsip Distribusi Islami oleh Pengusaha Peternakan

\begin{tabular}{ll}
\hline Nilai & Klasifikasi Penilaian \\
\hline $51-92$ & Tidak Baik \\
$93-134$ & Kurang Baik \\
$135-176$ & Cukup Baik \\
$177-218$ & Baik \\
$219-255$ & Sangat Baik \\
\hline
\end{tabular}


Pada responden pengusaha peternakan, berdasarkan data yang dikumpulkan melalui kuesioner dengan 109 butir pernyataan yang disebarkan kepada 51 responden, diperoleh item pernyataan penerapan prinsip distribusi islami yang tertinggi dengan skor 241 yang tergolong sangat baik yaitu pernyataan mengenai: bukan termasuk orang beriman meyakini Allah Swt. menciptakan segala sesuatu yang ada di langit dan di bumi tapi menyembah selain Allah Swt. Sedangkan item pernyataan dengan skor terendah yaitu 160, tergolong dalam klasifikasi cukup baik yaitu pernyataan mengenai: batasan - batasan dan ikatan - ikatan dalam distribusi tidak menghalalkan yang haram.

Selanjutnya analisis dilanjutkan dengan melakukan perhitungan Nilai Jenjang Interval (NJI) terhadap variabel prinsip distribusi islami sebagai berikut:

Nilai tertinggi variabel prinsip distribusi islami secara keseluruhan pada pengusaha peternakan: 51 × 5 × $109=27.795$

Nilai terendah variabel prinsip distribusi islami secara keseluruhan pada pengusaha peternakan: $51 \times 1 \times 109=5.559$

Jumlah kriteria pernyataan: 5

$$
\text { Maka NJI }=\frac{\text { Nilai Tertinggi }- \text { Nilai Terendah }}{\text { Jumlah Kriteria Pernyataan }}=\frac{27.795-5.559}{5}=4.447,2 \approx 4.447
$$

Dengan demikian, nilai 4.447 menjadi jarak interval dalam klasifikasi penilaian untuk variabel prinsip distribusi islami oleh pengusaha peternakan dalam penelitian ini. Kemudian dilakukan perhitungan klasifikasi penilaian untuk penerapan prinsip distribusi islami secara keseluruhan pada pengusaha peternakan dengan rincian pada tabel 3 sebagai berikut:

Tabel 3

\section{Klasifikasi Penilaian Variabel Prinsip Distribusi Islami secara Keseluruhan pada Pengusaha Peternakan}

\begin{tabular}{ll}
\hline Nilai & Klasifikasi Penilaian \\
\hline $5.559-10.006$ & Tidak Baik \\
$10.007-14.454$ & Kurang Baik \\
$14.455-18.903$ & Cukup Baik \\
$18.904-23.351$ & Baik \\
$23.352-27.795$ & Sangat Baik \\
\hline
\end{tabular}

Berdasarkan hasil perhitungan rekapitulasi terhadap tanggapan pengusaha peternakan atas penerapan prinsip distribusi islami pada pengusaha peternakan di Kota Tasikmalaya diperoleh total skor sebesar $\mathbf{2 2 . 8 3 1}$ dengan persentase 82,14\%. Hal ini menunjukkan bahwa penerapan prinsip distribusi islami oleh pengusaha peternakan di Kota Tasikmalaya termasuk dalam klasifikasi baik.

Untuk mengetahui ada tidak perbedaan penerapan dimensi prinsip distribusi islami diterapkan oleh pengusaha peternakan di Kota Tasikmalaya, dilakukan pengujian dengan Uji Chi Square dengan hasil sebagai berikut: 
Tabel 4

Chi-Square Test

\begin{tabular}{ll}
\hline Test Statistics & dimensi \\
Chi-Square & $1.349 \mathrm{E} 2^{\mathrm{a}}$ \\
df & 3 \\
Asymp. Sig. & .000 \\
a. 0 cells $(.0 \%)$ have expected frequencies less than 5. \\
The minimum expected cell frequency is 27.3.
\end{tabular}

Adapun hipotesis yang digunakan pada Chi-Square Test adalah sebagai berikut:

Ho: Tidak ada perbedaan penerapan dimensi distribusi islami oleh pengusaha peternakan di Kota Tasikemalaya.

$H_{a}$ : Ada perbedaan penerapan dimensi distribusi islami oleb pengusaba peternakan di Kota Tasikmalaya.

Hasil perhitungan menunjukkan bahwa hasil uji statistik menghasilkan nilai Chi-Square sebesar 134,9 dengan nilai probabilitas 0,000. Oleh karena nilai probabilitas $<\alpha=0,05$ maka hipotesis nol $\left(\mathrm{H}_{\mathrm{O}}\right)$ ditolak dan $\mathrm{H}_{\mathrm{a}}$ diterima, hal ini menyatakan bahwa ada perbedaan penerapan dimensi prinsip distribusi islami oleh pengusaha peternakan di Kota Tasikmalaya. Berdasarkan hal tersebut kemudian dilakukan analisis rata-rata untuk mengetahui dimensi prinsip distribusi islami mana yang paling dominan diterapkan oleh pengusaha peternakan di Kota Tasikmalaya. Berikut dijelaskan dalam tabel 5.

\section{Tabel 5}

\section{Analisis Rata-rata Perbedaan Penerapan Dimensi Distribusi Islami oleh Pengusaha} Peternakan di Kota Tasikmalaya

\begin{tabular}{lllll}
\hline Dimensi & Ketauhidan & Kesyukuran & Kebebasan & Keadilan \\
\hline Total Skor & 932 & 1,739 & 3,743 & 16,417 \\
Jumlah item & 4 & 8 & 18 & 79 \\
Rata-rata per item & 233,0 & 217,38 & 207,94 & 207,81 \\
\hline
\end{tabular}

Berdasarkan tabel 5 diketahui bahwa dimensi ketauhidan merupakan dimensi yang dominan diterapkan oleh pengusaha peternakan di Kota Tasikmalaya dalam melaksanakan penerapan prinsip distribusi islami.

\section{Analisis Nilai Jenjang Interval Setiap Indikator dan Variabel Prinsip Distribusi Islami Pengusaha Konfeksi Pakaian Muslim}

Analisis Nilai Jenjang Interval (NJI) pada responden pengusaha konfeksi pakaian muslim dilakukan untuk mengukur klasifikasi penilaian dari variabel dan setiap indikator dimensi distribusi islami yang diamati terhadap 88 orang responden pengusaha konfeksi. NJI dihitung dengan tahapan sebagai berikut: 
Nilai tertinggi indikator penerapan prinsip distribusi islami pada pengusaha konfeksi: 88 × $5=440$

Nilai terendah indikator penerapan prinsip distribusi islami pada pengusaha konfeksi: 88 × $1=88$

Jumlah kriteria pernyataan sebanyak: 5

$$
\text { Maka NJI }=\frac{\text { Nilai Tertinggi }- \text { Nilai Terendah }}{\text { Jumlah Kriteria Pernyataan }}=\frac{440-88}{5}=70,4 \approx 70
$$

Dengan demikian, nilai 70 menjadi jarak interval dalam klasifikasi penilaian untuk setiap indikator penerapan prinsip distribusi islami oleh pengusaha konfeksi pakaian muslim dalam penelitian ini. Berikut ditampilkan dalam tabel 6:

\section{Tabel 6}

\section{Klasifikasi Penilaian untuk Setiap Indikator Penerapan Prinsip Distribusi Islami oleh} Pengusaha Konfeksi Pakaian Muslim

\begin{tabular}{ll}
\hline Nilai & Klasifikasi Penilaian \\
\hline $88-158$ & Tidak Baik \\
$159-229$ & Kurang Baik \\
$230-300$ & Cukup Baik \\
$301-371$ & Baik \\
$372-440$ & Sangat Baik \\
\hline
\end{tabular}

Pada responden pengusaha konfeksi pakaian muslim, berdasarkan data yang dikumpulkan melalui kuesioner dengan 103 butir pernyataan yang disebarkan kepada 88 responden, diperoleh item pernyataan penerapan prinsip distribusi islami yang tertinggi dengan skor 423 dengan kategori sangat baik yaitu pernyataan mengenai: bukan termasuk orang beriman meyakini Allah Swt. menciptakan segala sesuatu yang ada di langit dan di bumi tapi menyembah selain Allah Swt. Sedangkan item pernyataan dengan skor terendah yaitu 353 dengan kategori baik, yaitu pernyataan mengenai: batasan - batasan dan ikatan ikatan dalam distribusi tidak menghalalkan yang haram.

Selanjutnya analisis responden pengusaha konfeksi dilanjutkan dengan melakukan perhitungan Nilai Jenjang Interval (NJI) terhadap variabel distribusi islami sebagai berikut:

Nilai tertinggi variabel prinsip distribusi islami secara keseluruhan

pada pengusaha konfeksi: 88 × 5 x $103=45.320$

Nilai terendah variabel prinsip distribusi islami secara keseluruhan

pada pengusaha konfeksi: $88 \times 1 \times 103=9.064$

Jumlah kriteria pernyataan sebanyak: 5

$$
\text { Maka NJI }=\frac{\text { Nilai Tertinggi }- \text { Nilai Terendah }}{\text { Jumlah Kriteria Pernyataan }}=\frac{45.320-9.064}{5}=7.251,2 \approx 7.251
$$

Dengan demikian, nilai 7.251 menjadi jarak interval klasifikasi penilaian variabel distribusi islami pengusaha konfeksi pakaian muslim. Kemudian dilakukan perhitungan 
klasifikasi penilaian untuk penerapan prinsip distribusi islami secara keseluruhan pada pengusaha konfeksi pakaian muslim dengan rincian pada tabel 7 sebagai berikut:

\section{Tabel 7}

Klasifikasi Penilaian Variabel Prinsip Distribusi Islami secara Keseluruhan pada Pengusaha Konfeksi Pakaian Muslim

\begin{tabular}{ll}
\hline Nilai & Klasifikasi Penilaian \\
\hline $9.064-16.315$ & Tidak Baik \\
$16.316-23.567$ & Kurang Baik \\
$23.568-30.820$ & Cukup Baik \\
$30.821-38.072$ & Baik \\
$38.073-45.320$ & Sangat Baik \\
\hline
\end{tabular}

Berdasarkan hasil perhitungan rekapitulasi terhadap tanggapan responden yakni pengusaha konfeksi pakaian muslim atas penerapan prinsip distribusi islami diperoleh total skor sebesar $\mathbf{4 0 . 0 5 1}$ dengan persentase 88,37\%. Hal ini menunjukkan bahwa penerapan prinsip distribusi islami oleh pengusaha konfeksi di Kota Tasikmalaya termasuk dalam klasifikasi sangat baik.

Adapun untuk mengetahui ada tidaknya perbedaan penerapan dimensi prinsip distribusi islami yang diterapkan oleh pengusaha peternakan di Kota Tasikmalaya, maka dilakukan pengujian dengan Uji Chi Square dengan hipotesis sebagai berikut:

Ho: Tidak ada perbedaan penerapan dimensi distribusi islami oleh pengusaha konfeksi pakaian muslim di Kota Tasikmalaya.

$H_{a}$ : Ada perbedaan penerapan dimensi distribusi islami oleb pengusaha konfeksi pakaian muslim di Kota Tasikmalaya.

Setelah dilakukan pengolahan data, maka hasil uji disajikan dalam tabel 8 berikut:

Tabel 8

\section{Chi-Square Test}

\begin{tabular}{ll}
\hline Test Statistics & dimensi \\
& $1.212 \mathrm{E} 2^{\mathrm{a}}$ \\
Chi-Square & 3 \\
df & .000 \\
Asymp. Sig. & a cells $(.0 \%)$ have expected frequencies less than \\
a. 0 The minimum expected cell frequency is 26.5. \\
\hline
\end{tabular}

Hasil perhitungan menunjukkan bahwa hasil uji statistik menghasilkan nilai ChiSquare sebesar 121,2 dengan nilai probabilitas 0,000 . Oleh karena nilai probabilitas $<\alpha=$ 0,05 maka hipotesis nol $\left(\mathrm{H}_{\mathrm{O}}\right)$ ditolak dan $\mathrm{H}_{\mathrm{a}}$ diterima, hal ini menyatakan bahwa ada 
perbedaan penerapan dimensi prinsip distribusi islami oleh pengusaha konfeksi pakaian muslim di Kota Tasikmalaya. Berdasarkan hal tersebut kemudian dilakukan analisis rata-rata untuk mengetahui dimensi prinsip distribusi islami mana yang paling dominan diterapkan oleh pengusaha konfeksi pakaian muslim di Kota Tasikmalaya. Berikut dijelaskan dalam tabel 9 .

\section{Tabel 9}

\section{Analisis Rata-rata Perbedaan Penerapan Dimensi Distribusi Islami oleh Pengusaha Konfeksi Pakaian Muslim di Kota Tasikmalaya}

\begin{tabular}{lllll}
\hline Dimensi & Ketauhidan & Kesyukuran & Kebebasan & Keadilan \\
\hline Total Skor & 3,749 & 1,984 & 6,632 & 27,686 \\
Jumlah item & 9 & 5 & 17 & 72 \\
Rata-rata per item & 416,56 & 396,80 & 390,12 & 384,53 \\
\hline
\end{tabular}

Berdasarkan tabel 9 diketahui bahwa dimensi ketauhidan merupakan dimensi yang dominan diterapkan oleh pengusaha konfeksi pakaian muslim di Kota Tasikmalaya dalam melaksanakan penerapan prinsip distribusi islami.

\section{Kesimpulan}

Hubungan antar-manusia baik secara personal maupun sosial yang lebih luas sudah diatur dalam Islam. Ekonomi Islam memiliki perhatian yang besar terhadap seluruh aspek kehidupan muslim agar seluruh sumber daya dimanfaatkan untuk mewujudkan maqasid syariah. Kegiatan konsumsi, produksi dan distribusi sebagai kegiatan inti dalam kehidupan ekonomi haruslah dilaksanakan sesuai dengan koridor Islam untuk mewujudkan falab bagi seluruh manusia. Sistem ekonomi yang menyimpang dari ajaran dan prinsip-prinsip syariah secara empiris dapat menyebabkan masalah-masalah ekonomi diantaranya kesenjangan dan ketidakadilan ekonomi. Oleh karena itu, Alquran dan Sunnah adalah sumber yang dapat dijadikan pedoman dalam mencapai keseimbangan, kemerataan, dan pertumbuhan ekonomi di masa yang akan datang.

Hasil penelitian menyatakan bahwa pemahaman prinsip distribusi islami oleh pengusaha makanan yang diwakili oleh pengusaha peternakan dan pengusaha bukan makanan yang diwakili oleh pengusaha konfeksi pakaian muslim menunjukkan nilai yang sangat tinggi yakni masing-masing mencapai 99,22\% dan 98,11\%. Adapun dimensi prinsip distribusi islami yang paling dominan diterapkan adalah dimensi ketauhidan dengan nilai ratarata per item sebanyak 233,0 dan 416,56. Implikasi dari hasil penelitian ini mendorong pengusaha muslim untuk menerapkan prinsip distribusi islami dalam aktivitas bisnisnya untuk mencapai kemashlahatan. Penerapan prinsip distribusi islami dalam kegiatan perekonomian yang dilakukan di Kota Tasikmalaya dapat dijadikan contoh empiris bagi wilayah lainnya dalam pelaksanaan aspek ekonomi Islam.

\section{Daftar Pustaka}

Ahmad, A. N., Rahman, A. A., \& Rahman, S. A. (2015). Assessing Knowledge and 


\section{Dinar. Vol 7, No 1: Januari 2020. 46-61 \\ ISSN: 2460-9889 (Cetak) \\ ISSN: 2580-3565 (Online)}

https://journal.trunojoyo.ac.id/dinar/index

DOI: https://doi.org/10.21107/dinar

Religiosity on Consumer Behavior towards Halal Food and Cosmetic Products. International Journal of Social Science and Humanity, 5(1), 10-14. https://doi.org/10.7763/IJSSH.2015.V5.413

Aisyah, M. (2016). Consumer Demand on Halal Cosmetics and Personal Care Products in Indonesia. Al-Iqtishad: Journal of Islamic Economics, 9(1). https://doi.org/10.15408/aiq.v9i1.1867

Aprianto, N. E. K. (2017). Kebijakan Distribusi dalam Pembangunan Ekonomi Islam. Jurnal Hukum Islam, 14(2), 73. https://doi.org/10.28918/jhi.v0i0.693

APRIANTO, N. E. K. (2018). Kemiskinan dalam Perspektif Ekonomi Politik Islam. ISLAMICONOMIC: Jurnal Ekonomi Islam, 8(2), 169-188. https://doi.org/10.32678/ijei.v8i2.60

Briliana, V., \& Noviana, R. (2016). The antecedents and outcome of halal cosmetic products: a case study in jakarta indonesia, 11(2), 1-9.

Holis, M. (2016). Sistem Distribusi dalam Perspektif. Masharif Al-Syariah, 1(2), 1-14.

Ibrahim, S. M. (2015). The Role of Zakat in Establishing Social Welfare and Economic Sustainability. International Journal of Management and Commerce Innovation, 3(1), 437-441.

Lailatussufiani, S., Burhan, M. U., \& Multifiah. (2016). The Utilization of Zakat , Infaq and Shadaqah for Community Empowerment ( Case Study of BAZNAS West Nusa Tenggara Province ). International Journal of Business and Management Invention, 5(10), 152160.

Madnasir, M. (2011). Distribusi dalam Sistem Ekonomi Islam. Muqtasid: Jurnal Ekonomi dan Perbankan Syariah, 2(1), 57. https://doi.org/10.18326/muqtasid.v2i1.57-71

Munthe, M. (2014). Konsep Distribusi dalam Islam. Jumal Syariah, 2(1), 70-88.

Nasution, F. Z., Mandasari, A. E., \& Billah, M. (2018). Assessing Factors Influencing the Purchase Decision of Cosmetics among Middle Class Female Muslims. Atlantis Press. https://doi.org/10.2991/miceb-17.2018.21

Rodin, D. (2016). Pemberdayaan Ekonomi Fakir Miskin dalam Perspektif Al-Qur'an. Economica: Jurnal Ekonomi Islam, 6(1), 71. https://doi.org/10.21580/economica.2015.6.1.787

Saparuddin. (2015). Skema Distribusi dalam Islam. Human Falah, 2(1), 152-168.

SARI, W. (2014). Produksi, Distribusi, dan Konsumsi dalam Islam. ISLAMICONOMIC: Jurnal Ekonomi Islam, 5(2), 1-34. https://doi.org/10.32678/ijei.v5i2.24

Turmudi, M. (2017). Produksi dalam Perspektif Ekonomi Islam. Islamadina, Volume XVI, 37-56. Retrieved from http://jurnalnasional.ump.ac.id/index.php/ISLAMADINA 